\title{
Öğrenme Stratejileri
}

DOI: $10.26466 /$ opus. 901943

\author{
*

\section{Etem Yesilyurt *} \\ * Doç. Dr., Akdeniz Üniversitesi, Eğitim Fakültesi, Konyaaltı / Antalya / Türkiye \\ E-Posta: etemyesilyurt@akdeniz.edu.tr ORCID: 0000-0002-7340-7536
}

\section{$\ddot{O} z$}

Bilimsel olarak çok yol kat edilmesine karşın öğrenmenin nasıl olduğu veya insanların nasıl öğrendiğgi konusunda tam olarak görüş birliğinin olduğu söylenemez. Birçok öğrenme kuramı, modeli, yaklaşımı, yöntemi, tekniği vb. değişken bir yandan öğrenmenin nasıl olduğunu diğer yandan da öğrenmeye rehber olan ilkeleri, kuralları teorik hatta uygulamalı olarak açıklamaya çalışmaktadır. Bunlardan biri de öğrenme stratejileridir. Öğrenme stratejilerinin genel özelliklerini açıklamak amacıyla yapılan bu çalışma içerisinde öğrenme stratejisi, öğrenme stratejilerinin çeşitleri ve bu çeşitlerin özelliklerine yer verilmiştir. Çalışma, nitel araştırma yaklaşım içerisinde yer alan doküman incelemesi yöntemiyle yürütülmüştür. Alanyazında öğrenme modelleri, stilleri, yöntemleri, öğrenmeyi ölçme ve değerlendirme konularında birçok çalışma bulunmaktadır. Öğrenme stratejileriyle ilgili çalışmaların da var olduğu gözlemlenmiş, genel olarak konunun çeşitli değiş̧kenlerle ilişkisi ele alınmıştır. Ancak teorik olarak öğrenme stratejilerini açıklayan az sayıda çalışmaya ulaşılmıştır. Her öğrenen adını ve içeriğini tam bilmeyerek bir veya birkaçö̆grenme stratejisi kullanabilir. Bu nedenle öğrenme stratejileri öğretmenler tarafindan zaman zaman öğrenme sürecine dâhil edilmeli, gerekirse uygulamalı şekilde öğrencilere gösterilmelidir. Özellikle bireysel farklar dikkate alındı ̆̆ında her öğrencinin öğrenme stratejisi tercihinin farklı olabileceği de göz önünde bulundurulmalıdır. Dolayısıyla kendine uygun olan öğrenme stratejilerini kullanan bir öğrencinin başarı düzeyi istendik yön ve düzeyde artacaktır. Çalışmanın alanyazına, öğretmen yetiştirme sürecine ve öğrencilerin çalışma becerilerine katkı să̆laması umulmaktadır.

Anahtar Kelimeler: Öğrenme, strateji, öğrenme stratejisi. 


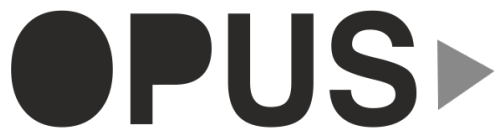

Uluslararası Toplum Araştırmaları Dergisi International Journal of Society Researches
E-ISSN : 2528-9535

YIl Year: 11

Cilt Volume: 18

Sayı Issue : Eğitim Bilimler Özel Sayısı

Eylül September 2021

Makalenin Gelis Tarihi Received Date: 23/03/2021

Makalenin Kabul Tarihi Accepted Date: 30/05/2021

\title{
Learning Strategies
}

\begin{abstract}
Although it has come a long way scientifically, it cannot be said that there is no consensus on how learning happens or how people learn. Many variables such as learning theories, models, approaches, methods, techniques, etc. try to explain on the one hand how the learning occurs on the other hand the principles and rules that guide learning theoretically and even practically. One of these is learning strategies. Learning strategies, types of learning strategies and the characteristics of these types are included in this study, which aims to explain the general characteristics of learning strategies. The study was conducted with the document review method included in the qualitative research approach. There are many studies in the literature on learning models, styles, methods, assessment, and evaluation of learning. It has been observed that there are also studies on learning strategies, and the relationship between the subject and various variables has been discussed. However, there are few studies that explain learning strategies theoretically. Each learner uses one or more learning strategies. The success level of a student who uses the learning strategies suitable for him/her will increase in the desired direction and level.
\end{abstract}

Keywords: Learning, strategy, learning strategy. 


\section{Giriş}

"Bireyin davranışlarında kendi yaşantısı yoluyla, kasıtlı olarak ve istendik yönde kalıcı izli değişiklik oluşturma süreci" olarak tanımlanan eğitim (Ertürk, 1972), bir bakıma "öğretme ve öğrenme" ana bileşenlerinin toplamını oluşturmaktadır. Eğitimin tanımı içerisinde yer alan bilişsel, duyuşsal ve devinişsel olarak da sınıflandırılan davranışların (Taşpınar, 2012) istendik şekilde değişikliği öğrenme ve öğretme sürecinin niteliğiyle yakından ilgilidir. Girdileri, işlemleri ve çıtılarıyla bir bütün olan eğitim sistemleri ve bu sistemin dersler, öğretim programları, okul yönetimi, öğretmen, veli gibi tüm paydaşları temelde öğrencinin davranışlarının istendik şekilde ve düzeyde değişikliğini sağlamak amacındadır. Nitekim bu durum bir öğretim programının başarısı ile bu başarının somut göstergeleri olan eğitimin genel ve uzak amaçlarına ulaşılma durumunun da bir göstergesidir. Eğitimin uzak ve genel amaçlarına istendik düzeyde ulaşılması için okulun fiziksel yapısının, araç-gereç ve imkânlarının yerinde, öğretmenlerin yeterli, öğrencilerin istekli, okul yönetiminin işlevsel ve öğretim programlarının nitelikli olması önemlidir (Akpınar, 2013; Alkan, 2005; Durukan, 2013; Şişman ve Turan, 2004; Turan ve Cansoy, 2021). Öte yandan öğrenme ve öğretme sürecinde yerinde, zamanında, amacına uygun olarak kullanılan veya kullanılması gereken öğrenme ve öğretme kuram1, modeli, stratejisi, stili, ilkesi, yöntemi ve tekniği de etkili ve işlevseldir (Demirel, 2007; Güneş, 2014; Özbek, 2011; Taşpınar ve Atıc1, 2002; Tok, 2012; Yeşilyurt, 2020a). Bu bağlamda Sönmez'e (2007) göre öğrencilerin bilişsel, duyuşsal ve devinişsel erişi (başarısı, davranış değişimi) düzeyi, Ertürk'e (1972) göre başarı, erişi, ürün ve öğrenme düzeyi hem öğretim programlarının başarı düzeyini hem de öğrenmenin yön ve düzeyini ortaya koyması bakımından önemlidir. Bu bakımdan öğrenmenin nasıl ve hangi şartlar altında olduğunun ve öğrenmeyi etkileyen faktörlerin neler olduğunun bilinmesi önem arz etmektedir (Senemoğlu, 2010; Seven ve Engin, 2008). Dolayısıyla öğrenmeyle ilgili bu ve benzeri sorulara yanıt olan / arayan çeşitli öğrenme kuram, model, yaklaşım, stil, ilke, yöntem ve teknikleri bulunmaktadır. Bunlardan biri de "öğrenme stratejileridir." 


\section{Çalışmanın Önemi}

Alanyazında öğrenme modelleri (Duman, 2007; Güneş, 2014; Seçer ve Ulaş, 2020; Yeşilyurt, 2020b), öğrenme stilleri (Evin-Gencel, 2006; Sidekli ve Akdoğdu, 2018; Yeşilyurt, 2019), öğrenme yöntemleri (Özbek, 2011; Uşun, 2007), öğrenmeyi ölçme ve değerlendirme (Gürsoy, 2017; Kuyumcu-Vardar ve Acar, 2018; Özenç ve Çakır, 2015; Yeşilyurt ve Semerci, 2013; Yeşilyurt, 2012) konularında birçok çalışma bulunmaktadır. Bunların yanı sıra bu çalışmanın konusu olan öğrenme stratejileriyle ilgili çalışmaların (Duman, 2008; Güven, 2004; Hamurcu, 2002; Yeşilyurt, 2013a) da var olduğu gözlemlenmiştir. Ancak öğrenme stratejileriyle ilgili yapılan çalışmaların geneli bu değişkenin başarı, motivasyon, bilişüstü, ölçek uyarlama vb. değişkenlerle ele alındığı görülmektedir. Ancak teorik olarak öğrenme stratejilerini açıklayan az sayıda çalışmaya (Erdem, 2005; Ozan, 2020; Özer, 2002; Subaşı, 2000) ulaşılmıştır. Öğrenme stratejilerini kuramsal olarak ele alması ve detaylı açıklaması bakımından bu çalışmanın alanyazına, öğretmen yetiştirme sürecine ve öğrencilerin çalışma becerilerine katkı sağlaması umulmaktadır.

\section{Çalışmanın Amacı}

Bu çalışma öğrenme stratejilerinin genel özelliklerini açıklamak amacıyla yapılmıştır. Bu genel amaç doğrultusunda aşağıdaki sorulara yanıt aranmiştır.

- Öğrenme stratejisi nedir?

- Öğrenme stratejilerinin çeşitleri ve bu çeşitlerin özellikleri nedir?

\section{Yöntem}

Çalışma, nitel araştırma yaklaşımı içerisinde yer alan doküman incelemesi yöntemiyle yürütülmüştür. Doküman incelemesi kısaca, bir araştırma verilerinin elektronik veya basılı materyallerinin sorgulanması, incelenmesi ve değerlendirilmesi süreci olarak tanımlanmaktadır (Bowen, 2009). Genel alanyazın taraması süreçlerini de içeren doküman incelemesi hem araştırmanın amacının yapılmasında yararlanılan yöntem hem de yöntemin uygulanması için kullanılan araç anlamındaki veri toplama tekniği 
olarak ele alınmaktadır (Özkan, 2019). Doküman incelemesi yöntemi, çalışma kapsamında ele alınan konunun başlıklarına öncelik veren veya odaklanana derleme çalışmasına (Aydoğdu, Karamustafaoğlu ve Bülbül, 2017) öncülük etmekte ve Herdman'a (2006) göre alanyazında yer alan çalışmaların fikir ve yaklaşımların özetlenmesine veya bu çalışmalar ış1ğında araştırmanın amacına uygun sentez oluşturulmasına fırsat tanımaktadır.

\section{Öğrenme Stratejisi}

Büyüme ve vücutta değişik etkilerle oluşan geçici süreli değişmelere atfedilmeyecek, yaşantı ürünü şeklinde meydana gelen davranışta veya potansiyel davranıştaki nispeten kalıcı izli değişmeye öğrenme denir (Senemoğlu, 2010). Strateji ise bir hedefe ulaşmak için geliştirilen bir planın uygulanması veya bir şeyi elde etmek için takip edilen yol (Açıkgöz, 2007); bir amaca varmak için gerekli olan işlemleri koordine etme ve planlama sanatı (De Villers 1992; Akt: Atan, 2005) şeklinde tanımlamaktadır. Öğrenme stratejileri, çoğunlukla bilişsel stratejiler olarak adlandırılır. $\mathrm{Bu}$ stratejilerin yararına ve önemine ilişkin görüş birliği olmasına rağmen belirgin bir sınıflama ve tanımlama için görüş birliğinin oluğunu ifade etmek zordur. Bu durum, öğrenme stratejisiyle ilgili birçok tanımın yapılmasına zemin hazırlamıştır (Güven, 2004).

Öğrenme stratejisi, bir öğrencinin bir konuyu veya içeriği kendi kendine öğrenmek amacıyla kullandığı işlemler (Gagne and Driscoll, 1988); öğrencilerin öğrenecekleri bilgiyi işleme şeklini etkileyen davranışlar veya öğrenme sürecinde uygulanan öğrenmeyi artırıcı eylemler (Mayer, 1989); öğrencilerin öğrenme sürecinde bilgiyi alma, onu belleğe kodlama ve gerektiğinde kodlanan bilgiye yeniden ulaşma süreçlerini etkilemesi beklenen düşünce ya da davranışlar; öğrencilerin neyi, nasıl, ne zaman öğrenmeleri gerektiğini bilmesiyle kendi öğrenmelerini yönlendirmeleri ve yapılandırmaları (Weinstein and Mayer, 1983); öğrencilerin bağımsız bir şekilde kendi öğrenme görevlerini yerine getirmelerini sağlayan teknikler, alışkanlıklar ve ilkeler (Sünbül, 2011) olarak tanımlanmaktadır. En genel ifadeyle öğrenme stratejileri, öğrencinin öğrenme-öğretme süreci içerisinde ya da bireysel öğrenme sürecinde öğrenmek için gerekli bilgileri zihinsel süreçlerinden geçirerek onu anlamlandırması, kendine mal etmesi 
veya içselleştirmesi için gerekli çaba veya eylemleri ortaya koyması şeklinde tanımlanabilir (Tay and Yangın, 2008). Bu tanımlara göre, öğrenme stratejileri öğrencinin kendi kendine öğrenmesinde yararlandığı öğrenmeyi kolaylaştırıcı davranışlar ve düşünceler olarak açıklanabilir. Bu alanda yapılan diğer tanım veya açıklamalara dayanarak öğrenme stratejilerinin özelliklerini ve kapsamını aşağıdaki gibi özetlenmek mümkündür. Öğrenme stratejileri:

- Bireysel tarz şeklinde gerçekleştirilen davranışlar olup öğrenme eylemiyle özdeş değildir.

- Belli bir hedef ve görev için bilinçli yönelimlerden veya çalışma şartları içerisinde bilinçsiz adaptasyonlardan oluşur.

- Psikolojik eylem düzenlemesinin bir bileşeni olarak duygu, biliş ve motivasyon gibi diğer psikolojik bileşenlerle entegredir (Kleppin, 2007; Akt: Taşçı, Altun ve Soran, 2008).

Öğrenme stratejileriyle ilgili tanım ve kavramlara bakıldığında vurgulanan ortak nokta, öğrenme stratejilerinin bireyin öğrenme sürecinde bilgiyi öğrenmek amacıyla yapması gereken davranış ve işlemleri bilinçli gerçekleştirdiği, öğrenme stratejisini kendisinin seçtiği ve bilginin kalıcı izli olmasını sağlayıcı davranışları sergilediği şeklinde olduğu görülmektedir.

Öğrenme stratejisinin amac1, öğrencinin yeni bilgiyi seçmesi, örgütlemesi ve bütünleştirmesini kolaylaştırmaktır. Öğrencilerin öğrenme stratejilerini anlamlı şekilde kullanmaları, aynı zamanda onların örtük program ve okul dışı faktörlerin de öğrenmede yerini almasına katkı sunmaktadır. Bu durum çoğunlukla kısıtlı olan okulda öğrenmenin (resmi programın) eksik yanlarının da tamamlanmasına yardımcı olmaktadır (Harmanlı, 2000). Öğrenme stratejilerinin öğrencinin kalıcı ve kolay öğrenmesini gerçekleştirmesinin yanı sıra diğer işlevleri de şöyle açıklanabilir (Özer, 2002). Öğrenme stratejileri öğrencinin;

- Bilinçli ve farkında öğrenici olmasını sağlar.

- Bağımsız öğrenme niteliği kazanmasını sağlar.

- Öğrenmedeki etkinliğini ve verimliliğini yükseltir.

- Okul sonrası veya dişı öğrenmesine temel hazırlar.

- Zevk alarak ve isteyerek öğrenmesine yardımcı olur. 


\section{Öğrenme Stratejilerinin Sınıflaması}

Öğrenciler bilgiyi öğrenirken farkında olarak ya da olmayarak çeşitli öğrenme stratejisi kullanır. Öğrenme konusuyla ilgili soru çıkarma ve bu soruları yanıtlama, öğrenilen bilgiyi özetleme, açıklama, grafik ve şekil gibi çeşitli görsel yollarla gösterme (Açıkgöz, 2007) gibi eylem ve etkinlikler öğrenme stratejilerinin kullanıldığını göstermektedir. Ayrıca, metin kenarına not alma, altını çizme, zihinsel tekrar, benzetimler kullanma, gruplandırma, örgütleme, uzamsal temsilciler oluşturma, kendi kendine soru sorma ve not alma vb. (Senemoğlu, 2010) gibi eylem veya davranışlar da öğrenme stratejileri arasında yer bulmaktadır.

Öğrencilerin bilerek veya bilmeyerek, farkında olarak veya olmayarak ama genellikle öğrenme sürecinde kullandıkları öğrenme stratejilerinin s1nıflandırması konusunda alanyazında tam anlamıyla bir birliğin olmadığı görülmektedir. Ancak Weinstein ve Mayer (1986) tarafından yapılan öğrenme stratejileri sinıflandırması alanyazında en fazla kabul görmektedir. Weinstein ve Mayer (1986), öğrenme stratejilerini ayrıntılı şekilde ve sekiz gruptan oluşan bir sınıflamaya tabi tutmuşlardır. İlgili sınıflamaya göre öğrenme stratejileri şu şekilde sınıflandırılmaktadır:

- Temel öğrenme tekrar stratejileri.

- Karmaşık öğrenme tekrar stratejileri.

- Temel anlamlandirma stratejileri.

- Karmaşık anlamlandırma stratejileri.

- Temel örgütleme stratejileri.

- Karmaşık örgütleme stratejileri.

- Kavramayı izleme stratejileri.

- Duyuşsal stratejiler.

Ancak Özer (2002), bu sinıflamada yer alan temel ve karmaşık stratejilerini birleştirmiş ve alanyazında yer alan birçok araştırmada daha fazla kabul gören şekliyle öğrenme stratejilerini beş sınıfla sınırlandırmıştır. Bu sınıflamaya göre öğrenme stratejileri aşağıdaki gibi sınıflandirılmaktadır:

- Tekrar / yineleme stratejileri.

- Anlamlandirma stratejileri.

- Örgütleme stratejileri.

- Anlamayı izleme stratejileri. 
- Duyuşsal stratejiler.

Bu çalışmada alanyazında daha fazla kabul gören şekli olan ve Özer'in (2002) sınıflamasında yer alan öğrenme stratejileri detaylı olarak ele alınmış ve açıklanmıştır.

\section{Yineleme (Tekrar) Stratejileri}

Olduğu gibi hatırlanması istenen bilgilerin öğrenilmesinde etkili olan yineleme stratejilerinin temelinde zihinsel yineleme yer almaktadır. Tekrar stratejisi bu nedenle genellikle öğrenme sürecinde temel öğrenmeler için kullanılmaktadır. Yineleme öğrenme stratejisi, öğrencilerin öğrenme sürecinde kendilerine sunulan içeriği etkin şekilde birer birer adlandırmaları veya sıralamaları anlamında kullanılmaktadır (Hasra, 2007). Kısa süreli hatırlamalar ve basit temel görevler için uygun olan yineleme stratejileri, üst düzey öğrenmeler için çok uygun veya etkili değildir. Sesli okuma, aynen yineleme, liste ezberleme, satır altı çizme ve değiştirmeden yazma yineleme stratejilerine örnek verilebilir (Özer, 2002). Tekrar stratejilerinin öğrencinin dikkatini metnin önemli bölümlerine yoğunlaştırmasına yardımcı olma (seçme) ile sonraki çalışmalar için materyalin işleyen belleğe aktarıldığından emin olma (kazanma) şeklinde iki temel bilişsel amacı bulunmaktadır (Demirel, 1993; Akt: Ozan, 2020). Yineleme içerisindeki olan bazı öğrenme stratejilerinin genel özelliklerine aşağıda yer verilmiştir.

Metinde Yazıların Altını Çizme: Temel düşüncelerin ve anahtar kelimelerin altının çizilmesi, öğrenciler tarafından yaygın şekilde kullanılan bir stratejidir. Altını çizme, okunan bir metinde, bölümde veya paragrafta önemli, gerekli olan ve olmayan düşüncelerin bir bakıma bilgilerin ayırt edilmesine dayanmaktadır. Özellikle daha alt öğretim kademesindeki öğrencilerin önemli olan ve olmayan düşünce ayrımını yapamaması ve ön bilgilerinin yetersiz olması nedeniyle bazı öğrenciler tüm cümlelerin altını çizme hatasını sergiler. Ancak farkında yapılan altını çizme, öğrenme açısından oldukça önemlidir. Arends, (1997; Akt: Erdem, 2005) altını çizmenin iki faydasını ön plana çıkarır. Birincisi, altını çizme anahtar kelimeleri, ana düşünceleri fiziksel bir şekilde yerleştirir, böylece hatırlama ve gözden geçirme hızlı ve etkili gerçekleşmektedir. İkincisi, altı çizilerek seçme süreci, var olan bilgiye yeni bilginin birleştirilmesine yardım etmektedir. 
Altını çizme temel düşüncelere ve anahtar noktalara okuyanın dikkatini odaklayacağı stratejilerden biri olmasına rağmen okul öncesi ve ilkokul gibi alt öğretim kademelerindeki öğrenciler için uygun olmayabilir. Altını çizme, okuyanın dikkatini anahtar noktalara veya temel düşüncelere odaklayacağı stratejilerden biridir (Subaşı, 2000; Erdem, 2005). Altını çizme, öğrenci, metindeki anahtar kelimeler ve önemli bilgiler üzerinde dikkati yoğunlaştırarak metni daha etkili ve hızlı olarak tekrar etme; öğrencinin ön bilgileriyle yeni bilgi arasında ilişki kurmasına destek olur (Ozan, 2020).

Aynı Sözcüklerle Not Alma (Değiştirmeden Yazma): Bu stratejide metin içerisindeki aynı kelimeler kullanılarak metnin kenarına not alınır veya yazılır. Metnin bir kenarına not alma veya tutma, öğrencinin içeriği tekrar etmesine, yeni bilgiyi öğrenmeye hazır olmasına ve onu anlamlı kodlamasına katkı sağlar. Özellikle yasa, yönetmelik, formül, başkent adları, savaş yılları, edebi türler gibi herkes tarafından aynı şekilde bilinmesi ve öğrenilmesi istenilen öğrenme konularında bu strateji kullanılabilir. Bir metin okunduktan sonra ihtiyaç duyulan bölümler veya yerler değiştirilmeden yani olduğu gibi birkaç defa yazılır (Erdem, 2005; Subaşı, 2000).

\section{Anlamlandırma Stratejileri}

Anlamlandırma stratejileri, kısa süreli bellekteki veya öğrencinin yeni edindiği bilgileri, var olan bilgileriyle ilişkilendirerek onu uzun süreli belleğe yerleştirmesi esasına dayanır (Demirel, 2012). Kalıcı ve anlamlı bilgi için, öğrencinin konuyla ilgili yeni bilgi öğrenmesi ve bu yeni bilgiyi önceki yaşantılarından kazandığ 1 bilgilerle bütünleştirme gerekmektedir (Taşpınar, 2012). Yeni bilgiyi daha anlamlı hale getirme işlevi gören anlamlandırma stratejisi, bilgi birimleri arasında ilişki kurarak anlamlı öğrenmenin gerçekleşmesini sağlamaktadır. Cümlede kullanma, zihinsel imge oluşturma, benzetim yapma, sözel bilgileri farklı şekillerde ifade etme, özetleme, soru yanıtlama ve not alma gibi eylemeler anlamlandırma stratejileri içerinde yer almaktadır (Özer, 2002). Anlamlandırma içerisinde yer alan bazı öğrenme stratejilerine ve bu öğrenme stratejilerinin genel özelliklerine aşağıda yer verilmiştir (Erdem, 2005; Subaşı, 2000). 
Zihinsel İmge Oluşturma: Özellikle çiftli çağrışım öğrenme, sıralı liste öğrenme veya serbest hatırlama durumlarında yararlanılmaktadır. Çiftli çağrışım öğrenmesinde "kitap-çocuk" şeklindeki bir kelime çiftini hatırlatmayı hedefleyen bir öğrenci, kitap okuyan bir çocuğu zihninde canlandırabilir. Ayrıca sıralı liste öğrenmesinde dizi olarak verilen sayı, resim ve sözcük gibi öğeler sıralı ve sırasız olarak öğrenilebilir.

Cümlede Kullanma: Anahtar kelime yöntemiyle birlikte yabancı dilde kelime öğrenmede, çeşitli konularla ilgili olguların ve kavramların öğrenilmesinde yararlanılır. Yabancı dil veya dil öğrenmede, derslerin konuları veya dersler arasında ilişki kurmada, pekiştirme yapmada işlevsel bir öğrenme stratejisidir.

Benzetim Yapma: Öğrenilmesi amaçlanan bilginin kazanılmış bilgiler aracılığı ve desteğiyle yapay benzerliklerinin kurulmasıdır. Önceki bilgiler kullanılarak yeni bilgilerin somut biçimde açıklanmasına katkı sağlar. Eklemlemeyi ve ilişkilendirmeyi sağlayan bir başka yol da karşılaştırmalardan yararlanmaktır. Düşünceler veya özellikler arasındaki ayrılıkları ve benzerlikleri karşılaştırarak gösterir. Metafor kullanımı, benzetim, analoji bu stratejiye uygun yollardir.

Özet Çıkarma: Ana çizgi ve noktalarıyla metni anlatmaktır. Özetlemede öğrenci, önemli düşüncelerle ayrıntıları ayırt eder, metindeki ana düşünceyi belirler, düşünceleri kendi cümleleriyle anlatarak bütünleştirir ve düşünceler arasında ilişki kurar. Metnin anlaşılmasını ve anımsanmasını kolaylaştıran özet çıkarma, yazılı bir materyalin öğrenilmesinde etkili bir öğrenme yoludur. Özet çıkarma özellikle uzun bilgilerin veya içeriğin yer aldığı kimi öğrenme sürecinde zamanda ekonomiklik ve bilgiyi kısa yoldan anlamlandırma için kullanımı gerekli olan bir stratejidir.

Not Alma: Metnin temel noktalarını ve bölümler arasındaki ilişikleri açıklayarak bilgileri daha kullanışlı ve anlamlı şekle dönüştürerek yazmadır. Doğru alınan not, yeni bilgi ile önceki bilgiyi etkili biçimde ilişkilendirir ve bilginin düzenlenmesine yardımcı olur. Ancak öğrencilerin çoğu metnin altını çizme stratejisinde olduğu gibi iyi not alamamakta, hatta öğren- 
cilerin bazıları öğretmenin konuştuğu veya anlattığı her şeyi yazmaktadırlar. Bu tür öğrenciler, önemli düşünceleri seçme ve bulmada, bunları amaca uygun tanımlamada güçlük yaşarlar. Öğretmenin her cümlesini yazan öğrenci, işlevsel not almayı bilmiyordur. Öte yandan bir konuşmacı dakikada ortalama 125 kelime kullanarak konuşmaktadır. Kısaltarak yazsa bile bir öğrencinin her söyleneni kaydetmesi oldukça zordur. Bu bakımdan etkili not alma, bireyin kendi cümleleriyle ana düşünceleri belirleme, önemli noktaları ve düşünceleri özetleyerek veya birleştirerek yeni bir biçim oluşturmaktır.

\section{Örgütleme Stratejileri}

Bu stratejilerde öğrenci ön bilgilerini kullanarak yeni bilgileri kendisi için daha anlamlı bir şekilde yeniden yapılandırır. Olguların ya da maddelerin taksonomi şekilde sınıflandırılması bu stratejilerin en temel düzeyini ve özelliğini oluşturur (Demirel, 2012). Anlamlandırma stratejilerindeki gibi bilginin anlamlandırılmasına önem veren örgütleme stratejileri, öğrenilecek bilgilerin tekrar organize edilip yapılandırılarak öğrenilmesini sağlar (Hasra, 2007). Ana çizgileri çıarma, sınıflandırma, kümelendirme, bilgi şeması oluşturma, çizelgeleştirme, aşamalı yapı oluşturma örgütleme stratejileri içerisinde yer almaktadır (Özer, 2002). Örgütleme içerisinde yer alan bazı öğrenme stratejilerinin genel özelliklerine aşağıda yer verilmiştir (Erdem, 2005; Özer, 2002; Subaş1, 2000).

Ana Çizgileri (Hatları) Çıkarma: Metnin yardımcı ve ana düşüncelerini kelime ve kelime öbekleri şeklinde belirlemedir. Öğrenci, öğrenme ünitesinin veya konusun ana ve alt başlıklarını çıkartıp bunlar arasında farklı ilişki kurabilir. Ana hatları çıkarmada, öğrenciler çeşitli konu veya düşünceleri bazı temel düşüncelerle ilişkilendirmeyi öğrenir. Özellikle konunun anlamlı öğrenilmesinden bir süre sonra kalıcllığı sağlama amaçlı genel tekrar yapma, içeriği gözden geçirirken dikkat çekme veya sadece önemli noktalara odaklanma açısından da önemli bir öğrenme stratejisidir.

Bilgi Şeması (Haritası) Oluşturma: Metindeki ana ve yardımcı düşüncelerin ilişkilerini aşamalı veya nedensel biçimde gösterilmesidir. Düşünceler arasındaki ilişkileri görselleştiren şemalaştırma (haritalama) metindeki 
önemli düşüncelerin birbirleriyle ilişkisinin kurulmasına yardımcı olur. $\mathrm{Bu}$ stratejiyle öğrenciler düşünceleri sıralamayı ve öğrenme konusunda belirlenen anahtar düşünceleri birbiriyle ilişkilendirmeyi öğrenir. Bilgi şemaları bezen aşamalı bazen de nedensel ilişkileri gösteren biçimde düzenlenir. Öğrencilere göre aynı zamanda eğlenceli olan bilginin şemalandırılması onların yeni materyali veya öğrenme konusunu daha etkili öğrenmesinde ve düşünceler arası ilişkileri anlamalarına oldukça fazla yardımcı olur.

Çizelgeleştirme: $\mathrm{Bu}$ öğrenme stratejisi, metindeki bilgileri dikey ve yatay bölmelere sahip bir çizelge şeklinde düzenleyerek ve bilgileri grupland1rarak bilgilerin birbiriyle ilişkisini kurmaya destek sağlar. Bu durumda bilgilerin arasında ilişkinin yönünün ve etkisinin belirlenmesi kolaylaşır.

Gruplandırma: Örgütleme stratejilerinden en çok kullanılanı gruplandırmadır. Gruplandırma, hatırlanması veya öğrenilmesi hedeflenen bilgi birimlerinin ortak özellikleri dikkate alınarak gruplara ayırmadır. Birden fazla ortak özelliğe sahip olan konu içeriklerinin birbiriyle ilişkisini ortaya koyması bakımından da işlevseldir.

\section{Anlamayı İzleme Stratejileri}

Anlamayı izleme stratejisi biliş hakkındaki bilgi ile bilişi izleme olmak üzere iki temel ögeden oluşmaktadır. Biliş hakkındaki bilgi, öğrencinin öğrenme yapısı ve materyali üzerinde kullanabileceği öğrenme stratejilerine ilişkin bilgisini ifade etmektedir. Bilişi izleme ise öğrencinin öğrenme materyalinin niteliğine uygun strateji seçebilmesi, kullanabilmesi, öğrenmenin aşamalarını düzenleyebilmesi ve değerlendirebilmesini kısacası bireysel öğrenme süreçlerini vurgulamayı ifade etmektedir (Nacaroğlu, 2019). Anlamayı izleme stratejileri, kendini sorgulama, sorunu belirleme, kendini değerlendirme, çalışmasını planlama ve hata düzeltme biçiminde sınıflara ayrılmaktadır. Anlamayı izleme içerisinde yer alan bazı öğrenme stratejilerinin genel özelliklerine aşağıda yer verilmiştir (Erdem, 2005; Özer, 2002). 
Sorunları Tanımlama ve Belirleme: Bu stratejide öğrenenin kendi öğrenmesi ve öğrenme süreciyle ilgili karşılaştığı sorunların farkına varması ve bunları tanımlaması ön plandadır. Bir öğrenci kendine "Benim öğrenmemin önündeki engeller nelerdir?", "Ben en fazla hangi konuları öğrenmede niçin zorluk yaşıyorum?", "Benim bu içeriği öğrenmem için sahip olmam, yapmam veya sakınmam gereken davranışlarım neler?" şeklindeki soruları yönelterek öğrenme için yaşadığı sorunları belirlemede ve bu sorunların üstesinden gelmede kullandığg önemli bir stratejidir.

Dikkatini Toplama ve Tepkilerini Yönlendirme: Öğrenme sürecinde bireyin dikkatini öğrenmeleri üzerine çekebilmesi, tepkilerini yönlendirebilmesi ve odaklanmayı sağlamasıyla ilgilidir. Öğrenme açısından son derece önemli olan dikkati toplama, anlık değil öğrenme süreci boyunca devam eden bir stratejidir.

Kendini Pekiştirme ve Değerlendirme: Bu strateji, bireyin kendi öğrenmeleri üzerinde durması, öz değerlendirme yapması, kendini pekiştirmesi ve öğrenip öğrenemediğini denetleyebilmesiyle ilgilidir. Bir bakıma öğrenenin kendi öğrenme düzeyini belirlemesi, bu düzeyin istendik yön ve seviyede olması durumunda kendini pekiştirmesidir.

Hatalarnı Düzeltme ve Çözüm Üretme: Bireyin, dönüt ve düzeltme mantığı içerisinde kendi öğrenmelerine ilişkin yaptığı hataları, yanlışları düzeltmesi ve bunları tekrarlamamasıyla ilgilidir. Bir öğrenenin hatalarını görmesi, bu hataları gidermesi veya tekrarlamaması için uygun çözüm önerileri ortaya koymasıyla ilgili bir öğrenme stratejisidir.

\section{Duyuşsal Stratejiler}

Öğrenciler öğrenme sürecinde kendilerine uygun öğrenme stratejilerini kullansalar bile kimi zaman dikkati toplayamama, olumsuz tutum, sınav kaygısı gibi duygusal faktörlerden kaynaklanan çeşitli zorluklarla karşılaşabilmektedirler. Bu sorunu aşmanın yolu öğrencinin kendini motive edecek bazı stratejileri kullanmasını gerektirmektedir. Bu stratejiler, öğrencilerin öğrenme sürecinde dikkati toplamak ve sürdürmek, konuya odak- 
lanmak, kaygıyı azaltmak, zamanı etkili kullanmak, motivasyonu sağlamak ve sürdürmek için kullanılmaktadır (Yüksel, 2014). Kısaca duyuşsal stratejiler, öğrenmede güdüsel ve duygusal faktörlerden oluşan engelleri gidermek amacıyla işe koyulan öğrenme stratejilerdir (Sönmez, 2008). Bu stratejiler, genel olarak öğrenme için uygun dişsal ve içsel koşulların oluşturulmasına ve sürdürülmesine destek sunmaktadır. Senemoğlu (2010) duyuşsal stratejileri, dikkati sürdürmeyi, uygunluğu, güveni ve doyumu artırmayı sağlayan duyuşsal stratejiler olmak üzere dört başlık altında ele almaktadır. Weinstein ve Mayer'a (1986) göre bu stratejiler arasında uyarıcılara karşı uyanık ve rahat olma, yoğunlaşmayı sürdürme, dikkati odaklama, öncelikli konuları belirleme, çalışacak sessiz bir yer seçme, olumlu tutum geliştirme, kaygıyı azaltma ve kendi kendine olumlu pekiştirmede bulunma gibi beceriler yer almaktadır. Duyuşsal içerisinde yer alan bazı öğrenme stratejilerinin genel özelliklerine aşağıda yer verilmiştir (Erdem, 2005; Subaşı, 2000; Özer, 2002).

Dikkat Yoğunlaştırma: Öğrenilen konu üzerinde dikkatin yoğunlaştırılmasıdır. Genellikle okurken ve çalışırken herhangi birinin içeri girmesi, radyonun açılması, dışardan gelen gürültü gibi dışsal etmenler dikkatin başka tarafa yönelmesine neden olmaktadır. Öğrenciler, ruhsal yapılarını uygun duruma getirerek etkili öğrenme için öğrenmelerini destekleyen en uygun çevresel özellikleri belirleyip bunları düzenlemektedir. Öğrenme sürecinde dikkatin dağılması kimi zaman belki de çoğu zaman öğrenenden de kaynaklanmaktadır. "Bunu anlayamadım”, "Bu projeyi yapma ihtimalim düşük" gibi olumsuz düşünme motivasyonu düşürmekte ve dikkati azaltmaktadır. Kısaca içsel ve dışssal koşulları en uygun duruma getirip öğrenme sürecinde öğrenme materyali üzerinde odaklanmak yani dikkati sağlamak önemli bir durumdur.

Olumlu Tutum Geliştirme: Tutum, bireyi belli durum, insan ve nesneler karşısında belirli davranışlar sergilemeye yönelten davranış eğilimleridir. Öğrencilerin okula, derse, öğretmene ve öğrenmeye karşı olumsuz tutumu onların öğrenmesini olumsuz yönde etkilemektedir. Etkili ve işlevsel öğrenme için eğer varsa bu olumsuz tutumun nedenleri tespit edilmeli ve giderilmeli, öğrencinin öğrenmeye karşı pozitif tutum kazanmasının 
önü açılmalıdır. Bir öğrencinin okula, derse, öğrenme, arkadaşlarına, sosyal ve fiziksel çevresine vb. karşı olumlu tutumu onun etkili, kalıcı ve anlamlı öğrenmesi için önemli bir gerekliliktir.

Güdülenme: Öğrenmesi için bireyi harekete geçiren güç kaynağıdır. Motive olmuş bir öğrenci öğrenmekten zevk alır, öğrenmek için sorumluluk alır ve sürekli çaba sarf eder. Güdüleme stratejisi, öğrenmeye karşı ilgiyi artırmada, yeni ve önceki bilgiyi bütünleştirmede yardımcı olmaktadır. Öğrenen kendine “Bu bilgi bildiklerimle uyuşuyor mu?" sorusunu yöneltmeli, eğer yeni ve önceki bilgi arasında uyuşmazlık varsa bu durumu ortadan kaldırmaya çalışmalıdır. Öğretim kademeleri dikkate alındığında alt kademelerde dışsal güdülenme, daha üst öğretim kademelerindeyse içsel güdülenme ön plandadır. Bu noktada gelişim dönemleri ve bu dönemlerin genel özellikleri motivasyonun çeşidini etkilemektedir.

Kaygıyı Azaltma (Güven Sağlama): Kaygı, güçlü dürtü ya da isteğin hedefe ulaşmasını engelleyen ve öğreneni tedirgin eden bir durum veya olgudur. Kaygı, en çok sınavlarda veya derslerde "başarılı olamama" duygusu olarak görülmektedir. Kaygının çok yüksek olması veya olmaması, öğrenme için olumsuz bir tabloyu meydana getirmektedir. Genelde ders çalışan öğrencilerde aşırı kaygı hali görülmektedir. Aşırı kaygı, öz-güven geliştirilerek, düzenli çalışarak ve başarı elde ederek giderilebilir. Öğrenmek için çaba harcamak ve amaca ulaşmak için inançlarını kullanmak bireyde güven durumu oluşturur. Güvenin sağlanmasında ve devamında olumlu öz-konuşmalar etkili olabilir. Ancak test kaygısı, verilen görevi yapamama korkusu ve anksiyete, güveni olumsuz etkileyen etmenler arasında yer almaktadır. Bir miktar kaygı ve güven öğrenme açısından oldukça önemlidir.

\section{Sonuç}

Öğrenmenin sınıf ortamında, “öğrencinin bir şeyi öğrenmeyi gerçekten istemesi durumunda gerçekleştiği" gerçeği göz önüne alındığında, öğrencinin öğrenmesi için öğrenciyi harekete geçirecek eylemlerin öğretmenlerce bilinmesi, bu eylemlerin sınıf ortamında ve öğrenme sürecinde bilinçli bir şekilde kullanılması gerekmektedir. Bu durum, öğrenilecek her 
konuda ve öğrenme ortamında geçerlidir (Acat ve Demiral, 2002). Öğrencilerin bilişsel, duyuşsal ve devinsel yönden başarılarını yükseltmenin ve onların gelecek yaşamlarında gelişime devamlı açık bireyler olmalarını sağlamanın en işlevsel yollarından biri, onlara kendi öğrenme yol, yöntem ve stratejilerinin öğretilmesidir. Öğrencilerin hem formal eğitim süreçlerinde hem de formal eğitimin dışında veya sonraki hayatlarında kendilerini geliştirebilmeleri ve içinde bulunduğumuz çağda yaşanılan gelişme ve değişmelere ayak uydurabilmeleri için öğrencilerin nasıl daha etkili öğrendiklerinin farkında, kendi öğrenmelerini izleme ve değerlendirme becerilerine sahip olmaları gerekmektedir. Öğretim kademeleri dikkate alındığında ilkokuldan başlayarak örgün eğitimin her kademesinde, öğrencilere öğrenme stilleri, bu stiller dikkate alınarak hangi şartlar altında daha etkili öğrendikleri, sınıfta veya başka bir mekânda kendi kendilerine ders çalışırken kullanabilecekleri ve kendilerine uygun olan öğrenme stratejileri öğretilmelidir (Çelenk ve Karakış, 2007). Öğrenciler öğrenme stratejilerinin farkında olmayabilir veya nasıl kullanıldığını bilmeyebilir. Bu nedenle öğrenme stratejileri öğretmenler tarafından zaman zaman öğrenme sürecine dâhil edilmeli, gerekirse uygulamalı şekilde öğrencilere gösterilmelidir.

İlkokul yıllarından başlayarak öğrencilerin birkaç öğrenme stratejisine sahip olması veya öğrenme stratejisi geliştirmesi oldukça önemlidir. Öğrenme sürecinde asıl olan öğrencinin aktifliğidir. Öğrenmenin etkili bir şekilde gerçekleşmesi için öğrencilerin sadece öğretmenin yaptıklarını gözlemeleri, anlattıklarını dinlemeleri, sunduğu ancak öğrenme için s1nırlı olan bilgileri tekrar etmeleri veya sadece öğretmenin yönerge veya yönlendirmesiyle hareket etmeleri yeterli değildir. Diğer bir deyişle, öğrenme-öğretme sürecinde öğretmenin aktif olması, öğrencilerin ise sadece öğretmenin davranışlarını gözlemeleri, öğrenme için gerekli ancak yeterli değildir (Özer, 1998). Öğrencinin öğrenme stratejilerini öğrenmesi; kendi öğrenme sürecini yönlendirmesinde, mesleki gelişimlerinde süreklilik sağlanmasında ve nihai olarak da toplumsal verimliliğin yükselmesinde önemli işleve sahiptir (Açıkgöz, 2007). Konuyla ilgili araştırmalar öğrenme stratejilerinin öğretiminin öğrencilerin öğrenme düzeyini ve kalıc1 öğrenmeyi anlamlı düzeyde artırdığını göstermektedir (Yeşilyurt, 2013b). Özellikle bireysel farklar dikkate alındığında her öğrencinin öğrenme stratejisi tercihinin farklı olabileceği de göz önünde bulundurulmalıdır. 
Dolayısıyla kendine uygun olan öğrenme stratejilerini kullanan bir öğrencinin başarı düzeyi istendik yön ve düzeyde artacaktır.

Uygun ve etkili öğrenme stratejileri kullanmazlarsa öğrencilerin başarıya ulaşmaları çok zor olacaktır. Ancak bir öğrencinin, herhangi bir derste akademik görevi yerine getirme sürecinde, yani bir bakıma öğrenme sürecinde, öğrenme stratejilerinden hangisini kullanacağına, o öğrenme stratejisini etkili şekilde kullanmasına ve strateji kullanmanın sonuçlarının değerlendirmesine etki eden birçok faktör bulunmaktadır. Öğrencinin başarı ya da başarısızlık durumu kullandığı öğrenme stratejileriyle de yakından ilişkilidir. Öğrenme sürecinde öğrencinin destek aldığ1 aile, yetişkinler, akranlar ve öğretmenleri de öğrencilerin öğrenme stratejilerini bilmelerini ve kullanmalarını etkiler. Bu noktada rol model davranışlar önemli bir yer tutmakta ve özellikle küçük yaştaki öğrenciler kendilerine model aldığı bireylerin öğrenme stratejilerini kullanabilmektedir. Bunların yanı sıra öğrenme stratejileri öğrencilerin sadece tutum, cinsiyet ve akademik başarılarından değil aynı zamanda motivasyonlarından, benlik algılarından, ön bilgi düzeyinden, epistemolojik inançlarından, öz-yeterliklerinden ve birçok diğer öğrenci kaynaklı değişkenden de etkilenmektedir (Nisbett and Shucksmith, 1986; Tuckman, 1996; Warr and Dowing, 2000; Rao and Moely, 2000; Ho, 1998; Akt: Özkal ve Çetingöz, 2006). Bu değişkenlerin hangisinin daha baskın olduğu özellikle öğretmenler tarafından bilinmeli, fark edilmesi ve gerekli çözüm yolları öğrencilere sunulmalıdır.

Bu durumda öğretmenin öğrenme stratejileri hakkında bilgi sahibi olması hatta bu stratejileri kullanmaları gerekmektedir. Bunu sağlamanın yolu ise hizmet öncesi öğrenme ve öğretme sürecinde özellikle öğretmenlik meslek bilgisi dersleri arasında kendine yer bulan "öğretim ilke ve yöntemleri”, "özel öğretim yöntemleri” gibi derslerde öğrenme stratejileri konusunda bilgi sahibi olmalarından veya hizmet içi eğitim sürecinde bu bilgiyi kazanımlarından geçmektedir. Bu bağlamda konu hakkında yeterli bilgi sahibi olan öğretmenin öğrenme stratejilerinin öğretimi hakkında Ozan'ın (2020) da belirttiği gibi doğrudan öğretim ve karşılıklı öğretme gibi farklı yaklaşımlar kullanılmakla birlikte, strateji öğretiminde her öğretmen sorumluluk almalı, derslerinde bu stratejilere (anlamlandırma, yineleme, örgütleme, duyuşsal ve anlamayı izleme) doğrudan veya dolaylı olarak değinmelidir. 


\title{
EXTENDED ABSTRACT \\ Learning Strategies
}

Etem Yeşilyurt

Akdeniz University

\begin{abstract}
Although it has come a long way scientifically, it cannot be said that there is no consensus on how learning happens or how people learn. Many variables such as learning theories, models, approaches, methods, techniques, etc. try to explain on the one hand how the learning occurs on the other hand the principles and rules that guide learning theoretically and even practically. One of these is learning strategies. Learning strategies are the ways that help the individuals' learning activities when they learn by themselves. Learning strategies, types of learning strategies, and the characteristics of these types are included in this study, which aims to explain the general characteristics of learning strategies. The study was conducted with the document review method included in the qualitative research approach. There are many studies in the literature on learning models, styles, methods, assessment, and evaluation of learning. It has been observed that there are also studies on learning strategies, and the relationship between the subject and various variables has been discussed. However, there are few studies that explain learning strategies theoretically. There are various definitions of learning strategies in the literature, albeit in a close sense. In general terms, learning strategy can be defined as behaviors that affect the way students process information or activities that increase learning during learning. Each learner uses one or more learning strategies either consciously or unconsciously despite not knowing its name and content.

The classification of learning strategies made by Weinstein and Mayer is the most accepted in the literature. According to the relevant classification, learning strategies are classified as follows:

- Basic learning repetition strategies.

- Complex learning repeat strategies.

- Basic interpretation strategies.

- Complex signification strategies.

- Basic organizing strategies.
\end{abstract}


- Complex organizing strategies.

- Conception monitoring strategies.

- Affective strategies.

However, Özer combined the basic and complex strategies in this classification and limited learning strategies to five classes, which is more accepted in many studies in the literature. According to this classification, learning strategies are classified as follows:

- Repeat strategies.

- Interpretation strategies.

- Organizing strategies.

- Understanding monitoring strategies.

- Affective strategies.

Repetition (repeat) strategies as underlining texts in the text and noting with the same words; interpretation strategies as creating mental imagery, using in sentences, simulating, summarizing and taking notes; organizing strategies as outlining, information scheming, scheduling and grouping; strategies for monitoring understanding as identifying and defining problems, focusing and directing their responses, self-reinforcement and evaluation, and correction of mistakes and solutions; affective strategies are subclassified as attention concentration, positive attitude development, motivation, and anxiety reduction strategies.

Learning strategies are influenced not only by students' attitude, gender and academic achievement but also by their motivation, self-perception, prior knowledge, epistemological beliefs, self-efficacy and many other student-driven variables. The most dominant of these variables should be known especially by teachers and the students should be noticed and the necessary solutions should be presented to them. Considering the educational levels, learning strategies should be taught to students at all levels of formal education, starting from primary school. Students may not be aware of learning strategies or know how to use them. For this reason, learning strategies should be included in the learning process from time to time by teachers, and should be shown to students in a practical way if necessary. It should be kept in mind that each student's choice of learning strategy may be different, especially when individual differences are taken into account. Therefore, the success level of a student who uses 
the learning strategies suitable for him will increase in the desired direction and level. When students are being learned fundamentals of concepts and principles of disciplines, at the same time they should be learned about learning strategies in schools. Students' being more active in the learning process is one of the important points. It is necessary for students to be able to orient themselves and have learning skills in order to keep up with the information age. This emphasizes that individuals are aware of their own learning styles and strategies in the realization of learning. It is important for students to know their learning styles and strategies, to overcome learning difficulties and to support independent learning skills. Every level of education particularly beginning elementary school, the courses should be included both the topics and learning strategies. Various suggestions on the subject have been given in the study. It is hoped that this study will contribute to the literature, teacher training process, and students' study skills in terms of theoretical handling and detailed explanation of learning strategies.

\section{Kaynakça/References}

Acat, M. B. ve Demiral, S. (2002). Türkiye'de yabancı dil öğreniminde motivasyon kaynakları ve sorunları. Kuram ve Uygulamada Eğitim Yönetimi, $31,312-329$.

Açıkgöz, K. Ü. (2007). Aktif öğrenme. İzmir: Biliş Yayınları.

Akpınar, B. (2013). Eğitimde program geliştirme. Ankara: Data Yayınları.

Alkan, C. (2005). Ĕğitim teknolojisi. Ankara: Anı Yayıncılık.

Atan, N. (2005). İkinci yabancı dil olarak Fransızca öğreniminde yineleme, ulamlama ve anlamlandırma stratejilerinin kalıcılığa etkisi. Uludağ Eğitim Fakültesi Dergisi, XVIII(2), 269-298.

Aydoğdu, Ü. R., Karamustafaoğlu, O. ve Bülbül, M. Ş. (2017). Akademik araştırmalarda araştırma yöntemleri ile örneklem ilişkisi: Doğrulayıcı doküman analizi örneği. Z.G. Ĕ̆itim Fakültesi Dergisi, 30, 556-565.

Bloom, B. S. (1976). Human characteristics and school learning (İnsan nitelikleri ve okulda öğrenme; Çev: D. A. Özçelik). Ankara: Pegem Akademi. (2016).

Bowen, G. A. (2009). Document analysis as a qualitative research method. Qualitative Research Journal, 9(2), 27-40. 
Çelenk, S. ve Karakış, Ö. (2007). Farklı öğrenme stillerine sahip öğrencilerin genel öğrenme stratejilerini kullanma düzeyleri, "AİBÜ. Örneği.". AİBÜ Ĕ̆itim Fakültesi Dergisi, 7(2), 31-49.

Demirel, Ö. (2007). Öğretim ilke ve yöntemleri: Öğretme sanatı. Ankara: Pegem A Yayıncilik.

Demirel, Ö. (2012). Eğitimde program geliştirme: Kuramdan Uygulamaya. Ankara: Pegem Akademi.

Duman, B. (2007). Süreç temelli öğrenme-öğretim modeli. Muğla Üniversitesi Sosyal Bilimler Enstitüsü Dergisi, 19, 37-61.

Duman, B. (2008). Öğrencilerin benimsedikleri eğitim felsefeleriyle kullanıldıkları öğrenme strateji ve öğrenme stillerinin karşılaştırılması. Çukurova Üniversitesi Sosyal Bilimler Enstitüsü Dergisi, 17(1), 203-224.

Durukan, E. (2013). Öğretmen görüşleri açısından Türkçe dersi öğretim programı kazanımları. Karadeniz Sosyal Bilimler Dergisi, 5(8), 1-14.

Erdem, A. R. (2005). Öğrenmede etkili yollar: Öğrenme stratejileri ve öğretimi. Ilköğretim-Online, 4(1), 1-6.

Ertürk, S. (1972). Ĕ̆itimde program geliştirme. Ankara: Yelkentepe Yayınları.

Evin-Gencel, İ. (2006). Öğrenme stilleri, deneyimsel öğrenme kuramına dayal e tim ve sosyal bilgiler program hedeflerine erişi düzeyi. Doktora Tezi. Dokuz Eylül Üniversitesi, Eğitim Bilimleri Enstitüsü, Eğitim Programları ve Öğretim Bilim Dalı, İzmir.

Gagne, R. M. and Driscoll, M. (1988). Essentials of learning for instruction. Englewood Cliffs, NJ: Prentice-Hall.

Güneş, F. (2014). Öğretim ilke ve yöntemleri (Ed: F. Güneş), Yaklaşım ve modeller (s.23-60). Ankara: Pegem Akademi.

Gürsoy, G. (2017). Ölçme ve değerlendirme okuryazarlı̆̆ı: Kavramsal bir analiz. Amasya Üniversitesi Eğitim Fakültesi Dergisi, 6(1), 281-316.

Güven, M. (2004). Öğrenme stilleri ile öğrenme stratejileri arasındaki ilişki. Doktora Tezi. Anadolu Üniversitesi, Eğitim Bilimleri Enstitüsü, Eğitim Programları ve Öğretim Ana Bilim Dalı, Eskişehir.

Hamurcu, H. (2002). Okulöncesi öğretmen adaylarının kullandıkları öğrenme stratejileri. Hacettepe Üniversitesi Eğitim Fakültesi Dergisi, 23, 127-134.

Harmanl, Z. (2000). Öğrenme stratejileri (Etkili öğrenme eğitimi). İzmir: Dokuz Eylül Üniversitesi Yayınları. 
Hasra, K. (2007). Beyin temelli öğrenme yaklaşımıyla öğrenme stratejilerinin öğretiminin öğrencilerin okuduğunu anlama becerisi üzerindeki etkisi. Yüksek Lisans Tezi. Muğla Üniversitesi, Sosyal Bilimler Enstitüsü, Eğitim Programları ve Öğretimi Ana Bilim Dalı, Muğla.

Herdman, E. A. (2006). Derleme makale yazımında, konferans ve bildiri sunumu hazırlamada pratik bilgiler (Çev. Z. Dörtbudak). Hemşirelikte Eğitim ve Araştırma Dergisi, 3(1), 2-4.

Kuyumcu-Vardar, A. ve Acar, F. (2018). Öğrenme-öğretme sürecinde kullanılabilecek hızlı ölçme araçları. Turkish Studies Educational Sciences,13(11), 879-898.

Mayer, R. E. (1989). Models for understanding. Review of Educational Research, 59(1), 43-64.

Nacaroğlu, D. (2019). Müzik öğretmeni adaylarımın kullandıkları öğrenme stratejilerinin çeşitli değişkenler açısından incelenmesi. Yüksek Lisans Tezi, Denizli: Pamukkale Üniversitesi.

Ozan, C. (2020). Öğrenmede klasik ve güncel yaklaşımlar (Ed: İ. Seçer ve S. Ulaş), Öğrenme stratejileri (s.257-277). Ankara: Vizetek Yayıncllık.

Özbek, R. (2011). Öğretim ilke ve yöntemleri (Ed. G. Ocak), Öğrenme-öğretme süreci (s.159-196). Ankara: Pegem Akademi Yayınları.

Özbek, R. (2011). Öğretim ilke ve yöntemleri (Ed: G. Ocak), Öğrenme-öğretme süreci (s.159-196). Ankara: Pegem Akademi Yayınları.

Özenç, M. ve Çakır, M. (2015). Sınıf öğretmenlerinin alternatif ölçme ve değerlendirme yeterliklerinin belirlenmesi. İlköğretim Online, 14(3), 914933.

Özer, B. (1998). Eğitim bilimlerinde yenilikler (Ed: H. Ayhan), Öğrenmeyi öğretme (s.147-162). Eskişehir: Anadolu Üniversitesi Açık Öğretim Fakültesi Yayınları.

Özer, B. (2002). İlköğretim ve ortaöğretim okullarının eğitim programlarında öğretim stratejileri. Eğitim Bilimleri ve Uygulama, 1(1), 17-32.

Özkal, N. ve Çetingöz, D. (2006). Akademik başarı, cinsiyet, tutum ve öğrenme stratejilerinin kullanımı. Kuram ve Uygulamada Eğitim Yönetimi, $46,259-275$.

Özkan, U. B. (2019). Eğitim bilimleri araştırmaları için doküman inceleme yöntemi. Ankara: Pegem Akademi.

Seçer, İ. ve Ulaş, S. (2020). Öğrenmede klasik ve güncel yaklaşımlar (Ed: İ. Seçer ve S. Ulaş), Öğrenmenin doğası ve temel kavramlar (s.1-22). Ankara: Vizetek Yayıncilı. 
Senemoğlu, N. (2010). Gelişim öğrenme ve öğretim: Kuramdan uygulamaya. Ankara: Gazi Kitabevi.

Seven, M. A. ve Engin, A. O. (2008). Öğrenmeyi etkileyen faktörler. Atatürk Üniversitesi Sosyal Bilimler Enstitüsü Dergisi, 12(2), 189-212.

Sidekli, S. ve Akdoğdu, E. (2018). Öğrenme stillerinin sınıf öğretmeni adaylarının akademik başarılarını yordama gücü. Hacettepe Üniversitesi Ĕğitim Fakültesi Dergisi, 33(2), 503-517.

Sönmez, V. (2007). Program geliştirmede öğretmen elkitabı. Ankara: Anı Yayınc1lik.

Sönmez, V. (2008). Öğretim ilke ve yöntemleri. Ankara: Anı Yayıncllık.

Subaşı, G. (2000). Etkili öğrenme: Öğrenme stratejileri. http://dhgm.meb.gov.tr/yayimlar/dergiler/MilliEgitim Dergisi/146/ subasi.htm. Erişim Tarihi: 04.02.2021.

Sünbül, A. M. (2011). Öğretim ilke ve yöntemleri. Konya: Eğitim Kitabevi.

Şişman, M. and Turan, S. (2004). Eğitim ve okul yöneticiliği el kitabı (Ed: Y. Özden), Eğitim ve okul yönetimi (s.99-146). Ankara: Pegem Akademi.

Taşçı, G., Altun, A. ve Soran, H. (2008). Biyoloji öğretmen adaylarının öğrenme stratejilerinin belirlenmesi üzerine nitel bir çalışma. Hacettepe Üniversitesi Ĕ̆itim Fakültesi Dergisi, 35, 284-296.

Taşpınar, M. ve Atıc1, B. (2002). Öğretim model, strateji, yöntem ve becerileri/teknikleri: Kavramsal boyut. Eğitim Araştırmaları, 2(8), 207-215.

Taşpınar, M. (2012). Kuramdan uygulamaya öğretim ilke ve yöntemleri. Ankara: Elhan Kitap Yayın Dağıtım.

Tay, B. ve Yangın, B. (2008). 4. sınıf öğrencilerinin sosyal bilgiler dersinde sınıf ortamında kullandıkları öğrenme stratejileri. Kırşehir Eğitim Fakültesi Dergisi, 9(3), 73-88.

Tok, Ş. (2012). Öğretim ilke ve yöntemleri (Ed: A. Doğanay). Öğretme-öğrenme strateji ve modelleri (s.129-160). Ankara: Pegem Akademi.

Turan, S. ve Cansoy, R. (2021). Yenilikçi Okullar: Özellikler, beceriler, stratejiler, uygulama örnekleri. Ankara: Nobel Akademik Yayıncllı.

Uşun, S. (2007). Öğretim ilke ve yöntemleri (Ed: Asuman, S. S. ve Hüseyin Hüsnü, B.), Öğretim yöntem ve teknikleri, (s.137-183). İstanbul: Lisans Yayıncilik.

Weinstein, C. E. and Mayer, R. E. (1983). The teaching of learning strategies. Innovation Abstracts, 5(32), 1-4. 
Weinstein, C. E. and Mayer, R. E. (1986). The teaching of learning strategies. In M. C. Wittrock (Ed.), Handbook of research on teaching (p.315-327). New York: Macmillan.

Yeşilyurt, E. ve Semerci, Ç. (2013). Öğretmenlik uygulaması öğretim programının standart temelli değerlendirme modeli ışığında değerlendirilmesi. Uluslararası Online Eğitim Bilimleri Dergisi, 5(1), 188-210.

Yeşilyurt, E. (2012). Öğretmen adaylarının ölçme ve değerlendirme alanına ilişkin genel yeterlik algıları. Mustafa Kemal Üniversitesi Sosyal Bilimler Enstitüsü Dergisi, 9(17), 377-395.

Yeşilyurt, E. (2013a). Öğretmenlerin öğrenme stratejilerine ilişkin algıladıkları farkındalık düzeyi. Türkiye Sosyal Araştırmalar Dergisi, 17(1), 113-135.

Yeşilyurt, E. (2013b). An analysis of teacher candidates' usage level of metacognitive learning strategies: Sample of a university in Turkey. Educational Research and Reviews, 8(6), 218-225.

Yeşilyurt, E. (2019). Öğrenme stili modelleri: Teorik temelleri bağlamında kapsayıcı bir derleme çalışması. OPUS-Uluslararası Toplum Araştırmalarn Dergisi, 14(20), 2169-2226.

Yeşilyurt, E. (2020a). Öğretmenin pusulası: genel öğretim ilkeleri. EKEV Akademi Dergisi, 24(83), 263-288.

Yeşilyurt, E. (2020b). Tam öğrenme yaklaşımı. İnsan ve Toplum Bilimleri Araştırmaları Dergisi, 9(2), 1548-1580.

Yüksel, S. (2014). Öğrenme öğretme kuram ve yaklaşımları (Ed: S. Fer), Ö ̆grenme stratejileri ve siniflamalar (s.149-167). Ankara: Anı Yayıncilık.

\section{Kaynakça Bilgisi / Citation Information}

Yeşilyurt, E. (2021). Öğrenme stratejileri. OPUS-Uluslararası Toplum Araştırmaları Dergisi, 18(Eğitim Bilimleri Özel Sayıs1), 5116-5139. DOI: 10.26466/opus.901943. 